\title{
Dietary intake and nutritional status of women and pre-school children in the Republic of the Maldives
}

\author{
Andrea M Golder' ', Jürgen G Erhardt', Veronika Scherbaum ', Mohamed Saeed², \\ Hans K Biesalski ${ }^{1}$ and Peter Fürst ${ }^{1, *}$ \\ 'Institute of Biological Chemistry and Nutrition, University of Hohenheim, Garbenstrasse 30, D-70599 Stuttgart, \\ Germany: ${ }^{2}$ UNICEF, Maldives, Goalhi No. 14, Bvruzo Mago, Male, Republic of the Maldives
}

Submitted 10 March 2000: Accepted 4 October 2000

\begin{abstract}
Objective: Malnutrition and poor nutritional status among children are common problems in the Republic of Maldives, a small island nation in the Indian Ocean. The aim of this study was to determine possible macro- and micronutrient deficiencies in the traditional Maldivian diet.

Design: In five atolls, 333 women with children aged between 1 and 4 years who were no longer breast-fed were interviewed, using a 24-hour recall. Additionally, the weights and heights of both the women and children were measured, and blood samples from 15 women were collected for measurements of vitamins A and E, $\beta$-carotene, homocysteine, cholesterol and haemoglobin.

Results: Of the women, 22\% had a body mass index (BMI) below 18.5. Of the children, $41 \%$ were stunted, $14 \%$ were wasted and 51\% were underweight. The women's and children's diets were sufficient in protein (14\%) and carbohydrates (67\%) but deficient in fat, which contributed only $19 \%$ to the total energy intake. Consumption of dietary substances that depend on vegetable and fruit intake (e.g. $\beta$-carotene, vitamin $C$, dietary fibre and folic acid) was low. The low intake of $\beta$-carotene was underlined by low plasma concentration. The estimated iron intake was low, although blood haemoglobin levels were normal.

Conclusions: Marginal nutritional status and marginal malnutrition are due to low fat intake and selected micronutrient deficiency. Higher intakes of locally available vegetables and fruits and fat (especially for children) on a regular basis might reverse the deficits documented on the atolls.
\end{abstract}

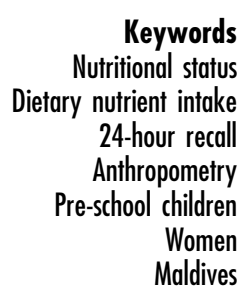

Malnutrition is a world-wide problem; both the impact on public health and its clinical form are seriously considered in communities. Children especially suffer from a marginal deprivation, or a mild chronic deficiency, of certain macro- and micronutrients resulting in growth retardation, loss of weight and proneness to infections.

Growth retardation among children is also a wellknown problem in the Republic of Maldives, a small island nation in the Indian Ocean. Despite a variety of locally available foods, the Maldivian diet might be described as monotonous, consisting mainly of fish (tuna fish and sometimes reef fish), rice and roshi (a kind of bread). Rice, flour, sugar, oil (except coconut) and milk powder are imported. Vegetables and fruit are rarely consumed; they are preferably sold if available $e^{2,3}$. The outlined dietary habits might result in micronutrient deficiency; iron ${ }^{2}$ and iodine deficiency ${ }^{5}$ are usual health problems. One-fifth of Maldivian children have a low birth weight $(<2.5 \mathrm{~kg})^{4}$, and the prevalence of malnutrition is reported to increase with age of the children ${ }^{1,2}$. Diarrhoea, acute respiratory infections and intestinal parasites are common associated diseases that have a negative impact on nutritional status ${ }^{3,6}$.

Although semi-quantitative data about food intake of women and children below 5 years old obtained by foodfrequency level (weekly food consumption without asking for portion sizes) are reported $^{2}$, quantitative information is not available. The present paper is the first attempt to appraise Maldivian food consumption patterns and nutrient intake. We used a retrospective, quantitative method (24-hour recall) in combination with a nutritional computer program, anthropometric measurements and, in a selected number of subjects, analyses of pertinent micronutrients and cholesterol in the plasma and haemoglobin in the blood were performed. 


\section{Subjects and methods}

\section{Study population}

The investigation was carried out in five of the 20 administrative atolls (Haa Dhaal, Kaaf, Laam, Meem and Gnaviyani) on a representative territorial basis selected throughout the Republic. In each atoll, one island was randomly selected. In certain instances an additional island, which was easy to reach from the randomly selected island, was included during the fieldwork. To be included in the study the criteria were women and children aged between 1 and 4 years who were no longer being breast-fed. The list of all households was prepared by the island administration office on each island. The first household on the list was taken randomly; the following households were taken systematically by selecting, for example, every second household on the list, depending on the total number of households required. In cases where the women had more than one child within the selected age group, the youngest child was chosen.

In total, 333 women aged 18-48 years (average: $29 \pm 6.5$ years) were interviewed. This included a representative number of children from the five atolls. Further analyses were possible in 307 women; 26 were excluded due to pregnancy. The distribution of the children was as follows: of a total of 333 children, 18 were aged one, 68 were aged two, 140 were aged three, and 107 were aged four. The children were assigned to two groups (1-3-year-old and 4-year-old children) according to WHO RDA groupings ${ }^{8,9}$. Only 312 children appeared for the measurement of weight and height (cf. also Table 1).

Blood samples after overnight fasting from 15 women in one atoll (Kaaf) could be collected for determination of iron, homocysteine, vitamins and cholesterol in the plasma, and haemoglobin in the blood. Informed consent was obtained. The inclusion criteria for the women were that they should be healthy, not more than 30 years old, not pregnant or breast-feeding, not taking vitamin or mineral supplements, and not using oral contraceptive agents.

Table 1 Percentage of children below -2 SD from the reference median (NCHS) according to height-for-age (HFA), weight-forheight (WFH) and weight-for-age (WFA)

\begin{tabular}{lccc}
\hline & \multicolumn{3}{c}{ Percentage of children $<-2$ SD } \\
\cline { 2 - 4 } & HFA (\%) & WFH (\%) & WFA (\%) \\
\hline All children $(n=312)$ & 40.9 & 14.4 & 51.1 \\
Sex & & & \\
$\quad$ Male $(n=171)$ & 37.8 & 15.2 & 47.4 \\
$\quad$ Female $(n=139)$ & 43.9 & 13.8 & 53.2 \\
Age (years) & & & \\
$1 \quad(n=15)$ & 20.0 & 20.0 & 31.3 \\
$2(n=61)$ & 30.2 & 11.3 & 44.3 \\
$3(n=133)$ & 44.4 & 18.9 & 56.3 \\
$4(n=103)$ & 45.1 & 9.7 & 49.0 \\
\hline
\end{tabular}

\section{Dietary assessment}

One complete 24-hour recall of food intake was carried out on each woman and her child. The 24-hour recall was modified to allow for Maldivian conditions. To help the women remember everything that had been consumed, they were asked to report systematically on their intake of beverages and food. For this purpose, common household vessels or utensils were used, such as a glass, cup, teaspoon, tablespoon or the special spoons normally used for rice or curry, and a measurement in inches for fish pieces. Amounts of sugar and milk powder were noted separately.

The questionnaire was pre-tested on one additional island and translated into the national language, Dhivehi. The interval of fieldwork was three months from December to the end of February. The compliance during the pilot phase as well as during the study period was very good. Altogether, only one family refused to participate in the survey. The interviews and measurements were supervised by one permanent survey team (nutritionist and a community health worker). In addition, there were two other trained teams that changed in every atoll, and which consisted mainly of students from whichever academic grades were the highest on that particular island (grades 7-10).

\section{Food analyses}

The estimated nutrient contents were computed at the University of Hohenheim (Stuttgart, Germany) with Ebis (FEP, Esslingen, Germany), a standard nutritional computer program. For this purpose the program was modified for the Maldivian conditions. Main preference was given to the Indian food composition table ${ }^{7}$ that was entered into the nutrient database of the Ebis program, because many Maldivian and Indian foods are comparable. Nutrients from commercial products were taken from the label. The recipes for common dishes were collected and entered as ingredients. The commonly used portion sizes were measured in grams with a weighing scale (Ovelys electronic kitchen scale, Tefal, Offenbach am Main, Germany) in some additional households.

The 24-hour recalls were compared with the WHO/ FAO recommendations ${ }^{8-12}$. If these were not available, the Indian recommended dietary allowances $(\mathrm{RDA})^{7}$ and, for the children, the USA $\mathrm{RDA}^{13}$ for vitamin $\mathrm{E}$ were applied. The energy requirements for the women were calculated individually according to their age, measured weight and height, plus an additional physical activity level for their work at home.

\section{Antbropometric assessment}

The weights of the women and children were measured whilst they were dressed in light clothes. For weight measurements the SECA personal weighing scale (used by UNICEF) was employed. The heights of the women, and of children above $90 \mathrm{~cm}$, were measured with a height- 
measuring device. The length of children below $90 \mathrm{~cm}$ was measured with an infantometer. Weight was recorded to the nearest $100 \mathrm{~g}$, and height or length to the nearest $0.1 \mathrm{~cm}$.

The National Center for Health Statistics (NCHS, Hyattsville, MD) reference growth data were taken as comparisons for the children. The share of children exhibiting growth retardation is defined as median (NCHS) minus two standard deviations (SD). The calculations were done with Epi Info 6.0.

For classification of the body mass index (BMI), the definition used by WHO/FAO was used to identify women who were underweight ${ }^{14}$ and overweight ${ }^{15}$.

\section{Laboratory analysis}

The blood samples were collected into tubes containing ethylene diaminetetraacetic acid (EDTA), immediately centrifuged and frozen at $-20^{\circ} \mathrm{C}$ until transported to the Institute of Biochemistry and Nutritional Science, University of Hohenheim, Stuttgart, Germany. The plasma samples were kept at $-80^{\circ} \mathrm{C}$ until analysed. The methods of Erhardt et al. ${ }^{16}$ were used. The haemoglobin concentration in the whole blood was estimated in the field with an electronic device called a 'HemoCue' (Ängholm, Sweden; haemoglobin-cyanide method). All variable coefficients of the integrated controls were below $6 \%$.

\section{Statistical analyses}

For statistical analyses, SPSS for Windows, version 7.5.2G, was used. The normality of the distribution of values was examined by using the Kolmogorov-Smirnov test (normal distribution, if $P>0.05$ ). In case of normal distribution the $t$-test for independent comparison was used; otherwise the Mann-Whitney $U$-test was applied. A difference was considered as significant if the $P$ value was $<0.05$. The results are expressed as mean \pm SD.

\section{Results}

Nutritional status of the children and their mothers Forty-one per cent of the children had low height-for-age (stunted, Table 1), 14\% had low weight-for-height (wasted) and 51\% had low weight-for-age (underweight). No significant differences between boys and girls were observed. For weight-for-height the trend showed an increasing prevalence of stunting with age, although the difference was only significant between the second and the fourth year.

The average anthropometric values for the women were $48.6 \pm 9.4 \mathrm{~kg}$ for weight, $149.4 \pm 5.5 \mathrm{~cm}$ for height and $21.8 \pm 4.0 \mathrm{~kg} \mathrm{~m}^{-2}$ for the BMI. In total, $22.0 \%$ of the women had a BMI below 18.5. Of these, $11.3 \%$ were classified as mildly underweight (BMI $=18.5-17 \mathrm{~kg} \mathrm{~m}^{-2}$ ), $6.2 \%$ as moderately underweight $\left(\mathrm{BMI}<17-16 \mathrm{~kg} \mathrm{~m}^{-2}\right.$ ) and $4.5 \%$ as severely underweight (BMI $<16 \mathrm{~kg} \mathrm{~m}^{-2}$ ). The majority of women $(58.4 \%)$ were found to be within the normal range $\left(\mathrm{BMI}=18.5-25 \mathrm{~kg} \mathrm{~m}^{-2}\right)$. Furthermore, $16.5 \%$ of the women were possibly overweight $\left(\mathrm{BMI}=25-30 \mathrm{~kg} \mathrm{~m}^{-2}\right)$ and $3.1 \%$ were overweight $\left(\mathrm{BMI}>30 \mathrm{~kg} \mathrm{~m}^{-2}\right)$. The BMI did not show any relationship to age.

\section{Average plasma levels of the women}

The results of selected biochemical variables in plasma are given in Table 2 . The mean plasma retinol concentra-

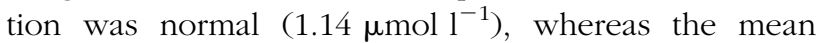
plasma $\beta$-carotene concentration $\left(0.11 \mu \mathrm{mol} \mathrm{l^{-1 }}\right)$ was low $\left(<0.3 \mu \mathrm{mol} \mathrm{l}{ }^{-1}\right)$. The average homocysteine (13.5 $\mu \mathrm{mol} \mathrm{l}^{-1}$ ) and $\alpha$-tocopherol $\left(148 \mathrm{mg} \mathrm{l}^{-1}\right.$ ) plasma levels were borderline high. Mean plasma concentration of cholesterol was normal. The haemoglobin level of $13.5 \mu \mathrm{mol} \mathrm{l}^{-1}$ was in the normal range of $12.2-$ $15.9 \mathrm{~g} / 100 \mathrm{ml}$, well above the values recommended by WHO (>12 g/100 ml).

\section{Dietary intake of the women}

The results of the 24-hour recalls of the women concerning their requirements are listed in Table 3 and compared with the RDAs from WHO or India. The average energy requirement of the Maldivian women was calculated to yield about $1900 \mathrm{kcal}$. In contrast, the actual mean energy intake was $1266 \mathrm{kcal}$, providing only 67\% of the energy requirement. The percentage of protein in the diet was 14\%, 17\% for fat and 69\% for carbohydrates. Protein consumption was $43 \pm 19 \mathrm{~g} \mathrm{day}^{-1}$, well within the range of the recommended protein allowance (41-48 g). The average fat intake was very low $(24 \pm 12 \mathrm{~g})$. The total carbohydrate intake was $215 \pm 78 \mathrm{~g}, 46 \mathrm{~g}$ derived from

Table 2 Haemoglobin and plasma concentration of selected vitamins and cholesterol

\begin{tabular}{lccr}
\hline & & \multicolumn{2}{c}{ Maldivian women } \\
\cline { 3 - 4 } Nutrient & Normal value & Mean $\pm \mathrm{SD}$ & Range \\
\hline Retinol $\left(\mu \mathrm{mol} \mathrm{I}^{-1}\right)$ & $1.05-2.27^{33}$ & $1.14 \pm 0.40$ & $(0.50-2.00)$ \\
$\beta$-Carotene $\left(\mu \mathrm{mol} \mathrm{I}^{-1}\right)$ & $\geq 0.3^{34}$ & $0.11 \pm 0.16$ & $(\mathrm{nd}-0.50)$ \\
Homocysteine $\left(\mu \mathrm{mol} \mathrm{I}^{-1}\right)$ & $5-13.4^{35,36}$ & $13.5 \pm 5.7$ & $(6.54-26.44)$ \\
$\alpha-$ Tocopherol $\left(\mu \mathrm{mol} \mathrm{I}^{-1}\right)$ & $15.3-34.8^{37,38}$ & $15.3 \pm 4.1$ & $(9.18-23.26)$ \\
Cholesterol $\left(\mathrm{mg} \mathrm{I}^{-1}\right)$ & $120-240^{39}$ & $148.3 \pm 16.6$ & $(108.55-176.19)$ \\
Haemoglobin $(\mathrm{g} / 100 \mathrm{ml})$ & $12.0-16.0^{26}$ & $13.5 \pm 1.1$ & $(12.2-15.9)$ \\
\hline
\end{tabular}

${ }^{*}$ Not detectable. 
Table 3 Nutrient intakes of the women. Mean values \pm SD, minimum and maximum values. As a comparison, WHO RDA and percentages of the recommended amounts are given

\begin{tabular}{|c|c|c|c|c|c|}
\hline \multirow[b]{2}{*}{ Nutrient } & \multicolumn{3}{|c|}{ Maldivian women } & \multirow[b]{2}{*}{ RDA } & \multirow[b]{2}{*}{ Percentage of RDA } \\
\hline & Mean $\pm S D$ & Minimum intake & Maximum intake & & \\
\hline Energy (kcal) & $1266 \pm 468$ & 299 & 3568 & $1930^{*}$ & 67 \\
\hline Protein (g) & $43 \pm 19$ & 8 & 99 & $41-48 \dagger$ & \\
\hline Fat $(\mathrm{g})$ & $24 \pm 12$ & 3 & 73 & & \\
\hline Carbohydrates (g) & $215 \pm 78$ & 48 & 693 & & \\
\hline Sucrose $(g)$ & $46 \pm 30$ & 1 & 217 & & \\
\hline Dietary fibre (g) & $8.3 \pm 6.6$ & 1.4 & 40.1 & $40 \ddagger$ & 21 \\
\hline Vitamin $A(\mu \mathrm{g})$ & $458 \pm 395$ & 3 & 3925 & 500 & 92 \\
\hline Retinol $(\mu \mathrm{g})$ & $399 \pm 307$ & 2 & 3459 & & \\
\hline Carotene (mg) & $0.36 \pm 1.35$ & 0 & 20.54 & $2.4 \ddagger$ & 15 \\
\hline Vitamin E eq. $\|(\mathrm{mg})$ & $4.8 \pm 2.7$ & 0.3 & 16.1 & $7.5-98 \S$ & 64 \\
\hline Vitamin $B_{1}(\mathrm{mg})$ & $0.72 \pm 0.31$ & 0.08 & 2.52 & 0.9 & 80 \\
\hline Vitamin $B_{2}(\mathrm{mg})$ & $0.53 \pm 0.36$ & 0.07 & 2.23 & 1.3 & 41 \\
\hline Vitamin $B_{6}(\mathrm{mg})$ & $1.01 \pm 0.45$ & 0.17 & 2.75 & $2 \ddagger$ & 51 \\
\hline Folic acid eq.\| $(\mu \mathrm{g})$ & $34 \pm 24$ & 5 & 152 & 170 & 20 \\
\hline Vitamin C (mg) & $21 \pm 29$ & 0 & 221 & 30 & 70 \\
\hline Iron (mg) & $8.7 \pm 3.3$ & 1.9 & 31.7 & $16^{5} q$ & 54 \\
\hline
\end{tabular}

* Average calculated energy requirement according to weight, height, age plus the physical activity level.

† Depending on digestibility and amino acid score ${ }^{9}$

$\ddagger$ Indian RDA ${ }^{7}$.

§Acceptable daily intake: $0.15-2 \mathrm{mg} / \mathrm{kg}$ body weight ${ }^{12}$.

TDiet of high iron availability ${ }^{8}$.

II Equivalent.

sucrose, $4 \mathrm{~g}$ from milk powder and the rest (165 g) from complex carbohydrates, mainly acquired from rice and flour. On average the diets contained $8 \mathrm{~g}$ of dietary fibre, providing only $21 \%$ of the RDA.

The vitamin A intake $(458 \pm 395 \mu \mathrm{g})$ was mainly covered through retinol $(399 \pm 307 \mu \mathrm{g})$ acquired from fish and milk powder, corresponding to $92 \%$ of the RDA. A small amount was provided by carotene $(0.36 \pm$ $1.35 \mathrm{mg}$ ) and contributed $15 \%$ of the RDA. The average vitamin $\mathrm{E}$ intake was calculated to yield $5 \mathrm{mg}$, the main sources being oil and fish. For the water-soluble vitamins, the average thiamine $\left(B_{1}\right)$ intake was about $0.7 \pm 0.3 \mathrm{mg}$, riboflavin $\left(\mathrm{B}_{2}\right)$ was $0.5 \pm 0.4 \mathrm{mg}$ and pyridoxine $\left(\mathrm{B}_{6}\right)$ was $1 \pm 0.45 \mathrm{mg}$, covering $80 \%, 41 \%$ and $51 \%$ of the RDA, respectively. The intake of folic acid was $34 \pm 24 \mu \mathrm{g}$, corresponding to only $20 \%$ of the RDA. Vitamin C consumption varied greatly $(21 \pm 29 \mathrm{mg})$, covering about $70 \%$ of the RDA. In one atoll (Gnaviyani) the women's food consumption was significantly richer in vitamin C ( $41 \pm 38 \mathrm{mg})$ and carotene $(0.57 \pm 1.30 \mathrm{mg})$ compared with the second highest atoll (Kaaf; $28 \pm 15 \mathrm{mg}$ and $0.37 \pm 0.44 \mathrm{mg}$, respectively). The iron intake was $9 \pm 3 \mathrm{mg}$ per day, providing $54 \%$ of the RDA.

\section{Food intake of the women}

Estimated amounts of major food items are listed in Table 4. A high consumption of carbohydrates is to be noted: $430 \mathrm{~g}$ of rice, $65 \mathrm{~g}$ of rosh $i$ (a kind of bread) and $36 \mathrm{~g}$ of sugar in tea on average have been consumed. Important protein sources were fish $(80 \mathrm{~g})$ and milk powder $(11 \mathrm{~g})$. The share of vegetable intake (mainly yam, onions and potatoes) was low (53 g). The reported intake of fruit and green leafy vegetables was also low, $14 \mathrm{~g} \mathrm{day}^{-1}$ and $2 \mathrm{~g} \mathrm{day}^{-1}$, respectively.

\section{Dietary intake of the children}

The average nutrient intakes of the groups of 1-3-yearold and of 4-year-old children are shown in Table 5 in comparison to the RDA from WHO or India.

The energy derived from carbohydrates, fat and protein expressed as the percentage of the total energy intake was: protein, $14 \%$ for all children's diets; fat, $21 \%$ (children aged 1 to 3 years) and 19\% (4-year-old children); carbohydrates, 65\% and 67\%, respectively. The mean total protein intake was $33 \pm 13 \mathrm{~g}$ for the $1-$ 3-year-old children, covering well the RDA (14-23 g) for this group of children. The average fat consumption was $22 \pm 11 \mathrm{~g}$, covering only $63 \%$ of the RDA. The mean total carbohydrate intake was $148 \pm 50 \mathrm{~g}$. Nearly $40 \%$ of the

Table 4 Mean estimated food intake $\left(\mathrm{g} \mathrm{day}^{-1}\right)$

\begin{tabular}{lc}
\hline Food intake & Amount (g) \\
\hline Rice (parboiled) & 430 \\
Roshi * & 65 \\
Sugar in tea & 36 \\
Milk powder & 11 \\
Fish (mainly tuna) & 80 \\
Vegetables† & 53 \\
Fruit & 14 \\
Green leafy vegetables & 2 \\
\hline
\end{tabular}

* Made of wheat, flour, oil and salt.

† Mainly yam, onions and potatoes. 
Table 5 Average intakes of the 1-3-year-old and 4-year-old children. Mean values \pm SD, WHO RDA and percentage intake of RDA are given for comparison

\begin{tabular}{|c|c|c|c|c|c|c|}
\hline \multirow[b]{2}{*}{ Nutrient } & \multicolumn{3}{|c|}{ 1-3-year-old children } & \multicolumn{3}{|c|}{ 4-year-old children } \\
\hline & Average intake $\pm S D$ & RDA & $\%$ of RDA & Average intake $\pm S D$ & RDA & $\%$ of RDA \\
\hline Energy (kcal) & $936 \pm 318$ & 1250 & 75 & $872 \pm 308$ & 1510 & 58 \\
\hline Protein $(\mathrm{g})$ & $33 \pm 13$ & $14-23^{*}$ & & $30 \pm 13$ & $18-26^{*}$ & \\
\hline Fat $(\mathrm{g})$ & $22 \pm 11$ & $35 \dagger$ & 63 & $19 \pm 10$ & 42† & 45 \\
\hline Carbohydrates (g) & $148 \pm 50$ & & & $144 \pm 49$ & & \\
\hline Sucrose $(\mathrm{g})$ & $57 \pm 28$ & & & $53 \pm 27$ & & \\
\hline Dietary fibre $(\mathrm{g})$ & $4.9 \pm 4.0$ & & & $4.7 \pm 2.9$ & & \\
\hline Vitamin A $(\mu \mathrm{g})$ & $500 \pm 315$ & 400 & 125 & $365 \pm 220$ & 400 & 91 \\
\hline Retinol $(\mu \mathrm{g})$ & $461 \pm 270$ & & & $332 \pm 206$ & & \\
\hline Carotene (mg) & $0.29 \pm 1.03$ & $1.6 \dagger$ & 18 & $0.24 \pm 0.43$ & $1.6 \dagger$ & 15 \\
\hline Vitamin E eq.§ (mg) & $3.1 \pm 1.7$ & $6 \pi$ & 52 & $3.5 \pm 2.2$ & 79 & 50 \\
\hline Vitamin $B_{1}(\mathrm{mg})$ & $0.48 \pm 0.21$ & 0.5 & 96 & $0.42 \pm 0.19$ & 0.7 & 60 \\
\hline Vitamin $B_{2}(\mathrm{mg})$ & $0.79 \pm 0.51$ & 0.8 & 99 & $0.51 \pm 0.31$ & 1.0 & 51 \\
\hline Vitamin $B_{6}(\mathrm{mg})$ & $0.68 \pm 0.28$ & $0.9^{2} \dagger$ & 76 & $0.62 \pm 0.29$ & $0.9 \dagger$ & 69 \\
\hline Folic acid eq.§ ( $\mu \mathrm{g})$ & $33 \pm 17$ & 40 & 83 & $25 \pm 13$ & 53 & 47 \\
\hline Vitamin C (mg) & $20 \pm 30$ & 20 & 100 & $15 \pm 15$ & 20 & 75 \\
\hline Iron (mg) & $4.7 \pm 1.9$ & $5 \ddagger$ & 94 & $4.8 \pm 1.8$ & $5^{3} \ddagger$ & 96 \\
\hline
\end{tabular}

* Depending on digestibility and amino acid score ${ }^{9}$.

$\dagger$ Indian RDA.

$\ddagger$ Diet of high iron availability ${ }^{8}$.

§ Equivalent.

II US RDA ${ }^{13}$

carbohydrates was consumed as sucrose ( $57 \pm 28 \mathrm{~g}$ ), whereas dietary fibre was low $(5 \mathrm{~g})$. The mean vitamin A intake of $500 \mu \mathrm{g}$ was adequate (125\% of the RDA), whereas the average carotene intake was very low $(0.3 \pm 1.0 \mathrm{mg})$, corresponding only $18 \%$ of the RDA. The mean vitamin $\mathrm{E}$ content of the diet was $3.1 \pm 1.7 \mathrm{mg}$. Thiamine $(0.5 \pm 0.2 \mathrm{mg})$, riboflavin $(0.8 \pm 0.5 \mathrm{mg})$ and vitamin $\mathrm{B}_{6}(0.7 \pm 0.3 \mathrm{mg})$ corresponded to $96 \%$, $99 \%$ and $76 \%$ of the RDA, respectively. Folic acid intake (33 $\pm 17 \mu \mathrm{g})$ covered $83 \%$ of the RDA. On average, the vitamin C intake fulfilled the RDA (100\%). The diet contained about $5 \pm 2 \mathrm{mg}$ of iron, corresponding to about $94 \%$ of the RDA.

The average energy intake $(872 \pm 308 \mathrm{kcal})$ of the 4 year-old children was not significantly different from the energy intake of the 1-3-year-old children (936 \pm $318 \mathrm{kcal}$ ). The same or even lower intakes were found for micronutrients in the older children. Vitamins $\mathrm{A}$ and $\mathrm{B}_{2}$ were significantly lower in the diets of the 4-year-old children $(365 \pm 220 \mu \mathrm{g}$ and $0.51 \pm 0.31 \mu \mathrm{g}$, respectively) than in the diets of the 1-3-year-old children $(500 \pm 315 \mu \mathrm{g}$ and $0.79 \pm 0.51 \mathrm{mg}$, respectively).

The average milk powder intake of all the children was $32 \mathrm{~g} \mathrm{day}^{-1}$ with great variations between the atolls and depending on the age of the children. Milk powder contributed, on average, $17.5 \%$ of the children's energy intake, $42 \%$ of their fat and $26 \%$ of their protein intake.

Vitamin supplements were not considered in these evaluations. Seventy-one per cent of the women reported no vitamin supplements, whereas 29\% used supplements for the reference child. The supplements given consisted mainly of vitamins A and D, and C. Rarely were iron supplements reported.

\section{Discussion}

Nutritional status of the children and their motbers The average BMI of non-pregnant women in the present study $\left(21.8 \pm 4.0 \mathrm{~kg} \mathrm{~m}^{-2}\right)$ corresponded highly with a BMI of $21.3 \pm 3.8 \mathrm{~kg} \mathrm{~m}^{-2}$ observed in a previous national survey $^{2}$.

The percentage of children below -2 SD for height-forage was, however, higher in the present study (41\%) than in the Multiple Indicator Cluster Survey (MICS, 32\%) from $1996^{1}$. This survey reported a higher percentage of wasted children (19\%), compared with 14\% found in the present study. The percentage of underweight children ( $49 \%$ as against 51\% in this survey) was however similar. It should be noted that children aged from 0 to 60 months were enrolled in the MICS survey, whereas in the present study only a few children aged 1 and 2 years could be considered. Therefore, the higher percentage of low height-for-age children observed in the present study might be explained by the increasing prevalence of stunting as the children grow older ${ }^{1,2}$.

\section{Plasma analysis of the women}

The plasma samples could be collected in one atoll only and they thus represent a small share of the women participating in the study ( 15 women). However, the results derived from this selected group of women are the first plasma studies from the Maldives, and they confirm convincingly the estimated intakes of nutrients. 
Retinol is stored in the liver and regulated in the blood homeostatically by that organ, even in the presence of a marginal deficiency. Therefore, plasma retinol levels hardly indicate a marginal deficiency ${ }^{17,18}$. Generally the borderline concentration of $0.70 \mu \mathrm{mol} \mathrm{l}^{-1}$ is considered as the level below which retinol deficiency might be accounted for ${ }^{19,20}$. In the present study, all of the women except two had adequate plasma concentrations. This indicates that the majority of women might not be at risk for vitamin A deficiency, except when insufficient amounts of fish (in combination with milk powder) are consumed. The very low concentrations of $\beta$-carotene suggest that $\beta$-carotene-rich vegetables and fruit were rarely consumed despite their availability in the Maldives. It is assumed that $\beta$-carotene plasma levels of $\geq 0.4 \mu \mathrm{mol} \mathrm{l}^{-1}$ indicate protective effects ${ }^{21}$. This level may correspond to an intake of $2-5 \mathrm{mg} \beta$-carotene per day and could easily be reached by the Maldivian women.

Homocysteine is an intermediary metabolite in the metabolism from methionine to cysteine; folic acid, pyridoxine and vitamin $\mathrm{B}_{12}$ are necessary cofactors in this pathway. A deficiency of one or more of these vitamins leads to an extracellular accumulation of homocysteine $^{22}$. Although in the present study the mean value was within the normal range, five out of 15 women showed high homocysteine plasma levels which might be due to low folic acid and vitamin $\mathrm{B}_{6}$ intakes; intake of both vitamins were low in the nutritional surveys.

The plasma cholesterol levels in the lower normal range (average $148 \mathrm{mg} / 100 \mathrm{ml}$ ) might be due to the very low fat intake. It is well known that, in adults, $\alpha$ tocopherol plasma levels are closely correlated with cholesterol and total lipid concentrations ${ }^{23,24}$ as well as to the intake of polyunsaturated fatty acids (PUFA) ${ }^{25}$. The plasma concentration of $\alpha$-tocopherol in the Maldivian women was low, which is also explained by the extremely low intake of fat (energy) in the diet.

The main characteristic of the third and final stage of iron deficiency is a reduction in the concentration of haemoglobin in the red blood cells. None of the women measured was found with a level below $12 \mathrm{~g} / 100 \mathrm{ml}$ (WHO recommendation), indicating that they were not at risk for iron deficiency due to a reduction of haemoglo$\operatorname{bin}^{26}$. This observation was surprising because anaemia is reported to be a problem in the Maldives. According to a recent survey done in 1994, 62\% of the non-pregnant women had levels below the WHO-recommended value ${ }^{2}$. Our finding might be due to the use of iron tablets in this atoll, which was not recorded during the study. Iron folate tablets are regularly distributed to pregnant women by the health centres.

\section{Dietary intake of the women}

To interpret the nutritional intake of the women and children, the provision of the recommended dietary intake was assessed by setting the reference value for an insufficient supply at $75 \%$, according to Houshiar-Rad et $a$. $^{27}$

The results of the present study indicate that most women had a balanced energy intake and expenditure (58\% of the women had a BMI between 18.5 and 25). The finding that the BMI did not increase or decrease with age also underlines this assumption. It is conceivable that the women were adapted to lower caloric intake from childhood onwards due to their small height $(149 \mathrm{~cm})$. Yet a noticeable number of women were still underweight (22\%). This can indeed be a risk factor, especially during episodes of illness, pregnancy and lactation ${ }^{28}$. The low estimated energy intake might also be influenced by underestimation or erroneous definitions of portion sizes, factors that represent general problems in retrospective nutritional interviews ${ }^{29}$. To limit this effect, the reported energy intake was compared with the calculated energy needs as suggested by Hambraeus ${ }^{30}$. However, corrections to reach the calculated energy demand of $1930 \mathrm{kcal}$ did not normalise the intakes up to the range of the recommended requirements. This was especially true for $\beta$-carotene, folic acid, dietary fibre, iron and vitamin $\mathrm{B}_{2}$. The energy percentage of fat of the women's diet (17\%) was also below the FAO requirement for women of childbearing age, which might lead to a deficiency of essential fatty acids ${ }^{31}$.

Vitamin $\mathrm{C}$ and carotene intakes varied greatly among the women, because different amounts of vegetables and fruit were consumed. In one atoll (Gnaviyani) the women's food consumption was richer in vitamin $\mathrm{C}$ and carotene. Due to a lower availability of fresh fish and a more fertile soil on that island, fresh fish was more likely to be consumed with vegetables, as an ingredient of vegetable curry, rather than as a plain fish curry or as boiled fish. Indeed, the low intakes of vitamin $C$ and $\beta$ carotene are surprising considering that a high intake of these vitamins could easily be achieved by consuming larger amounts of certain tropical vegetables and fruit, like papaya or mango (for $\beta$-carotene) and guava, papaya or lemon (for vitamin $\mathrm{C}$ ), all of which are available in the Maldives or even grown in home gardens. Besides vitamin $\mathrm{C}$ and $\beta$-carotene, other active substances in plant foods like phyto chemicals were also lacking.

The Maldivian diet might yield high iron availability because fish (15\% iron absorbed) is often part of the meal $^{8}$. Despite this, the intakes acquired from the 317 women were low and corresponded to only $54 \%$ of the RDA. Additionally, non-nutritional factors known as public health problems in the country, like parasites and infections, exert a negative influence on iron status ${ }^{3,6}$. Therefore, low haemoglobin blood levels would be expected in the majority of the women ${ }^{2}$. Surprisingly, however, this was not the case in the 15 women whose blood samples were investigated. 


\section{Dietary intake of the children}

The diet of the 1-3-year-old children seemed to be better than that of the 4-year-old children and the women, especially with respect to milk powder vitamin constituents. This was the case for vitamin A, folic acid, and vitamins $\mathrm{B}_{2}$ and $\mathrm{B}_{6}$. In general, the 1-year-old children received more milk powder than the 4 -year-old children, which was not always compensated for by increasing amounts of staple foods. The 4-year-old children, therefore, seemed to achieve the same or a slightly lower intake of micronutrients than the younger children, although their need is increased. Also, vitamins and nutrients that are mainly covered through vegetables and fruit ( $\beta$-carotene, dietary fibre) were low in both the $1-3$ year-old and the 4-year-old children. Vitamin A seemed to be sufficient in the diets of all children (125\% and 91\% of the RDA, respectively) due to the use of milk powder, consumption of tuna fish and imported fortified foods like biscuits. Importantly, therefore, vitamin A deficiency is probably not a general problem among Maldivian children.

The adequate protein intake and the low fat content of the Maldivian diet is partly due to tuna fish, especially when the tuna fish is consumed as garudiya fish (boiled fish) or fish curry with rice or roshi, rather than as fried fish or fried snacks. The major fat sources were vegetable oil, coconut and milk powder. Considering that breast milk provides between 50 and 60\% of energy as fat, great caution should be exercised to prevent subsequent deficiency during and after the weaning period. Notably, only $21 \%$ of the total energy intake was fat for the $1-3$ year-old children in the present study instead of the required $30-40 \%{ }^{31}$. Certainly the low fat intake is probably one of the most important influencing factors in the high prevalence of malnutrition in Maldivian children $^{32}$.

\section{Acknowledgements}

We would like to express our sincere gratitude to UNICEF for financing this research and to the Department of Public Health (Maldives) for providing much-needed assistance. Special acknowledgement goes to Mohamed Ismael Didi (Supervisor, DPH) for his willing and generous co-operation during the fieldwork as well as to the interviewers in each atoll. We would also like to thank all the women and children for their good-natured participation in the survey.

\section{References}

1 UNICEF, Maldives. Multiple Indicator Cluster Survey Report [unpublished]. Maldives: United Nations Children's Fund, 1996.

2 DPH, Ministry of Health and Welfare, WHO and UNICEF. Nutritional Status and Child Feeding Practices of Maldivian Children - Report of the National Nutrition Survey [unpublished]. Maldives: Department of Public Health, Ministry of Health and Welfare/World Health Organization/ United Nations Children's Fund, 1994.

3 Chakravarty I. National Plan of Action for Nutrition of the Republic of Maldives [unpublished]. Maldives: World Health Organization, 1994.

4 Saeed M. Growth Chart Analysis Report [unpublished]. Maldives: United Nations Children's Fund, 1995.

5 Pandav CS. Iodine Deficiency Disorders in Maldives [unpublished]. Maldives: United Nations Children's Fund, 1995.

6 Khanu S, Saeed M. Maldives Parasite Survey Report [unpublished]. Maldives: World Health Organization and United Nations Children's Fund, 1995.

7 Gopalan C, Rama Sastri BV, Balasubramanian SC. Nutritive Value of Indian Foods. Hyderabad: National Institute of Nutrition, Indian Council of Medical Research, 1991.

8 FAO. Requirements of Vitamin A, Iron, Folate and Vitamin B12. Report of a Joint $\mathrm{FAO} / \mathrm{WHO}$ Expert Consultation, Geneva, 1985. FAO Food and Nutrition Series No. 23. Rome: United Nations Food and Agricultural Organisation, 1988.

9 WHO. Energy and Protein Requirements. Report of a Joint FAO/WHO/UNU Expert Consultation. WHO Technical Report Series No. 724. Geneva: World Health Organization, 1985.

10 FAO. Traditional Food Plants. FAO Food and Nutrition Paper No. 42. Rome: United Nations Food and Agricultural Organisation, 1988.

11 FAO. Requirements of Ascorbic Acid, Vitamin D, Vitamin B12, Folate and Iron. Report of Joint FAO/WHO Report Group. Rome: United Nations Food and Agricultural Organisation, 1970.

12 WHO/FAO. $\alpha$-Tocopherol. In: Toxicological Evaluation of Certain Food Additives and Contaminants. WHO Food Additive Series No. 21. Cambridge: World Health Organization/United Nations Food and Agricultural Organisation, 1987; 55-69.

13 Dietary Reference Intakes: Application in Dietary Assessment. Washington: National Academy Press, 2000.

14 Shetty PS, James WPT. Body Mass Index - A Measure of Chronic Energy Deficiency in Adults. FAO Food and Nutrition Paper No. 56. Rome: United Nations Food and Agricultural Organisation, 1994.

15 Latham MC. Human Nutrition in the Developing World. FAO Food and Nutrition Series No. 29. Rome: United Nations Food and Agricultural Organisation, 1997.

16 Erhardt JG, Heinrich F, Biesalski HK. Determination of retinol, antioxidant vitamins and homocysteine in skin puncture blood. Int. J. Vitam. Nutr. Res. 1999; 69: 309-14.

17 Olson JA. Serum levels of vitamin A and carotenoids as reflectors of nutritional status. J Natl. Cancer Inst. 1984; 73: 1439-44.

18 Gerlach T, Biesalski HK, Bassler KH. Serum vitamin A determinations and their value in determining vitamin $\mathrm{A}$ status. Z. Ernabrungswiss. 1988; 27: 57-70.

19 Pilch SM. Analysis of vitamin A data from the Health and Nutrition Examination Surveys. J. Nutr. 1987; 117: 636-40.

20 WHO. Indicators for Assessing Vitamin A Deficiency and their Application in Monitoring and Evaluating Intervention Programmes. Micronutrient Series No. WHO/NUT/96.10. Geneva: World Health Organization, 1996.

21 Biesalski HK, Böhles H, Esterbauer H, Fürst P, Gey F, Hundsdörfer G, Kasper H, Sies H, Weisburger J. Consensus statement: antioxidant vitamins in prevention. Clin. Nutr. 1997; 16: 151-5.

22 Pietrzik K, Bonstrup A. Vitamins B12, B6 and folate as determinants of homocysteine concentration in the healthy population. Eur. J. Pediatr. 1998; 157(Suppl): 135S-8S.

23 Vatassery GT, Kezowski AM, Eckfeldt JH. Vitamin E concentration in human blood plasma and platelets. Am.J. Clin. Nutr. 1983; 37: 1020-4. 
24 Jordan P, Brubacher D, Moser U, Stähelin HB, Gey KF. Vitamin $\mathrm{E}$ and vitamin A concentrations in plasma adjusted for cholesterol and triglycerides by multiple regression. Clin. Chem. 1995; 41: 924-7.

25 Machlin LJ. Vitamin E. In: Machlin LJ. Handbook of Vitamins. New York: Marcel Dekker, 1991.

26 ACC/SCN. Controlling Iron Deficiency. Nutrition Policy Discussion Paper No. 9. Geneva: Administrative Committee on Coordination/Sub-Committee on Nutrition, 1991.

27 Houshiar-Rad A, Omidvar N, Mahmoodi M, Kolahdooz F, Amini M. Dietary intake, anthropometry and birth outcome of rural pregnant women in two Iranian districts. Nutr. Res. 1998; 18: 1469-82.

28 Moore SE. Nutrition, immunity and the fetal and infant origins of disease hypothesis in developing countries. Proc. Nutr. Soc. 1998; 57: 241-7.

29 Bingham SA. The dietary assessment of individuals; methods, accuracy, new techniques and recommendations. Nutr. Abstr. Rev. 1987; 57: 705-42.

30 Hambraeus L. Dietary assessments: how to validate primary data before conclusions can be drawn. Scand. J. Nutr./ Nabringsforskning 1998; 42: 66-8.

$31 \mathrm{FAO}$ /WHO. Fats and Oils in Human Nutrition. Report of a Joint Expert Consultation. Food and Nutrition Paper No. 57.
Rome: United Nations Food and Agricultural Organisation, 1994.

32 Skinner JD, Carruth BR, Houck KS, Coletta F, Cotter R, Ott D, McLeod M. Longitudinal study of nutrient and food intake of infants aged 2 to 24 months. JAMA 1997; 97: 496-504.

33 Linder MC. Nutritional Biochemistry and Metabolism. London: Prentice Hall International, 1991.

34 Stähelin HB, Gey KF, Eichholzer M, Lüdin E. $\beta$-Carotene and cancer prevention: the Basel study. Am. J. Clin. Nutr. 1991; 53: $265 \mathrm{~S}-9 \mathrm{~S}$

35 Bergström J, Alvestrand A, Fürst P, Lindholm B. Sulphur amino acids in plasma and muscle in patients with chronic renal failure: evidence for taurine depletion. J. Intern. Med. 1989; 226: 189-94.

36 Suliman ME, Anderstam B, Bergström J. Evidence of taurine depletion and accumulation of cysteinesulfinic acid in chronic dialysis patients. Kidney Int. 1996; 50: 1713-7.

37 Reaven PD, Witztum JL. Oxidized low density lipoproteins in atherogenesis: role of dietary modification. Annu. Rev. Nutr. 1996; 16: 51-71.

38 Gaby SK, Machlin LJ. Vitamin Intake and Health, A Scientific Review: Vitamin E. New York: Marcel Dekker, 1991.

39 Curtis HC, Roth M. Clinical Biochemistry, Principles and Methods. Berlin/New York: Walter de Gruyter, 1974. 